Mădălin-Sebastian Lung*, Gabriela-Alina Mureșan * *

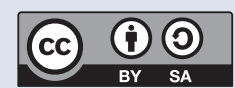

\title{
MIGRATORY DYNAMICS OF THE
} RURAL POPULATION OF THE APUSENI MOUNTAINS IN THE POST-SOCIALIST

\section{PERIOD}

Izvirni znanstveni članek

COBISS 1.01

DOI: $10.4312 /$ dela.53.131-150

\section{Abstract}

The aim of the present article is to draw up an analysis on the migratory dynamics of the population from the Apuseni Mountains in the Post-Socialist era. In order to accomplish this aim, we collected statistical data from two representative years, namely 1992 and 2011, which correspond to two censuses. The analysis was meant to reveal the evolution of the settlements (people who settled in the area) and of emigration, as registered in the two reference years and to identify the causes that determined the evolution of the emigration and immigration.

Key words: migratory dynamics, rural population, Apuseni Mountains, net migration rate, ArcGIS

*Babeș-Bolyai University, Doctoral School of Geography, Faculty of Geography, 400006, Cluj-Napoca, Romania

**Babeș-Bolyai University, Faculty of Geography, Department of Regional Geography and Spatial Planning, 400006, Cluj-Napoca, Romania e-mail: lungmadalin@yahoo.com, alina.muresan@ubbcluj.ro 


\section{MIGRACIJSKA DINAMIKA PODEŽELSKEGA PREBIVALSTVA V GORSKI POKRAJINI APUSENI V POSTSOCIALISTIČNEM OBDOBJU}

\section{Izvleček}

Namen članka je predstaviti analizo migracijske dinamike prebivalstva $\mathrm{v}$ gorski pokrajini Apuseni v postsocialističnem obdobju. Za dosego tega cilja smo zbrali statistične podatke dveh popisov prebivalstva iz let 1992 in 2011 . Analiza razkriva razvoj naselij (prebivalstva, ki se je naselilo na tem območju) in procese izseljevanja, ki so evidentirani na podlagi omenjenih popisov, ter identificira razloge za procese izseljevanja in priseljevanja.

Ključne besede: migracijska dinamika, podeželsko prebivalstvo, gorstvo Apuseni, selitveno gibanje, ArcGIS

\section{INTRODUCTION}

The aim of this article is to draw up an analysis of the migratory dynamics of population in the rural areas of the Apuseni Mountains. In order to analyse the emigration and immigration phenomena in the rural areas of the Apuseni Mountains, we considered statistical data for the years 1992 and 2011. The present study is needed because of some risk phenomena (depopulation, migration) which mostly affect the rural areas of the Apuseni Mountains. The present study completes another study (Lung, 2018), in which the analysis was focussed on the natural dynamics of the rural population in the Apuseni Mountains. That study emphasised great dysfunctionalities in population natural dynamics, thus only 10 communes, out of the total of 140 , registered positive growth rate.

The Apuseni Mountains (Figure 1) are a mountainous group-part of the Romanian Carpathians, which occupy areas within six Romanian counties: Alba, Arad, Bihor, Cluj, Hunedoara and Sălaj. The area of this Carpathian region is $10,750 \mathrm{~km}^{2}$. The Apuseni Mountains border Barcău Valley in the North and Mureș Valley in the South, Transylvanian Depression in the East and Western Hills in the West. They have three peaks over $1800 \mathrm{~m}$ : Gilău-Muntele Mare 1,826 m; Vlădeasa 1,836 m and Bihor 1,849 $\mathrm{m}$ - the maximum altitude in the Apuseni Mountains (Pop, 2000).

In a study by Mureşan (2016), the Apuseni Mountains are considered a demographically critical region, which implies the existence of demographic phenomena that have a negative impact on the population. Ten years ago, Cândea et al. (2006) had stated that the Apuseni Mountains were a disadvantaged region, and after five years, Drăgan (2011) categorised the Apuseni Mountains as a peripheral region. The most recent study conducted on these mountains (Surd et al., 2017) makes a detailed 
Figure 1. The geographic location of the Apuseni Mountains.

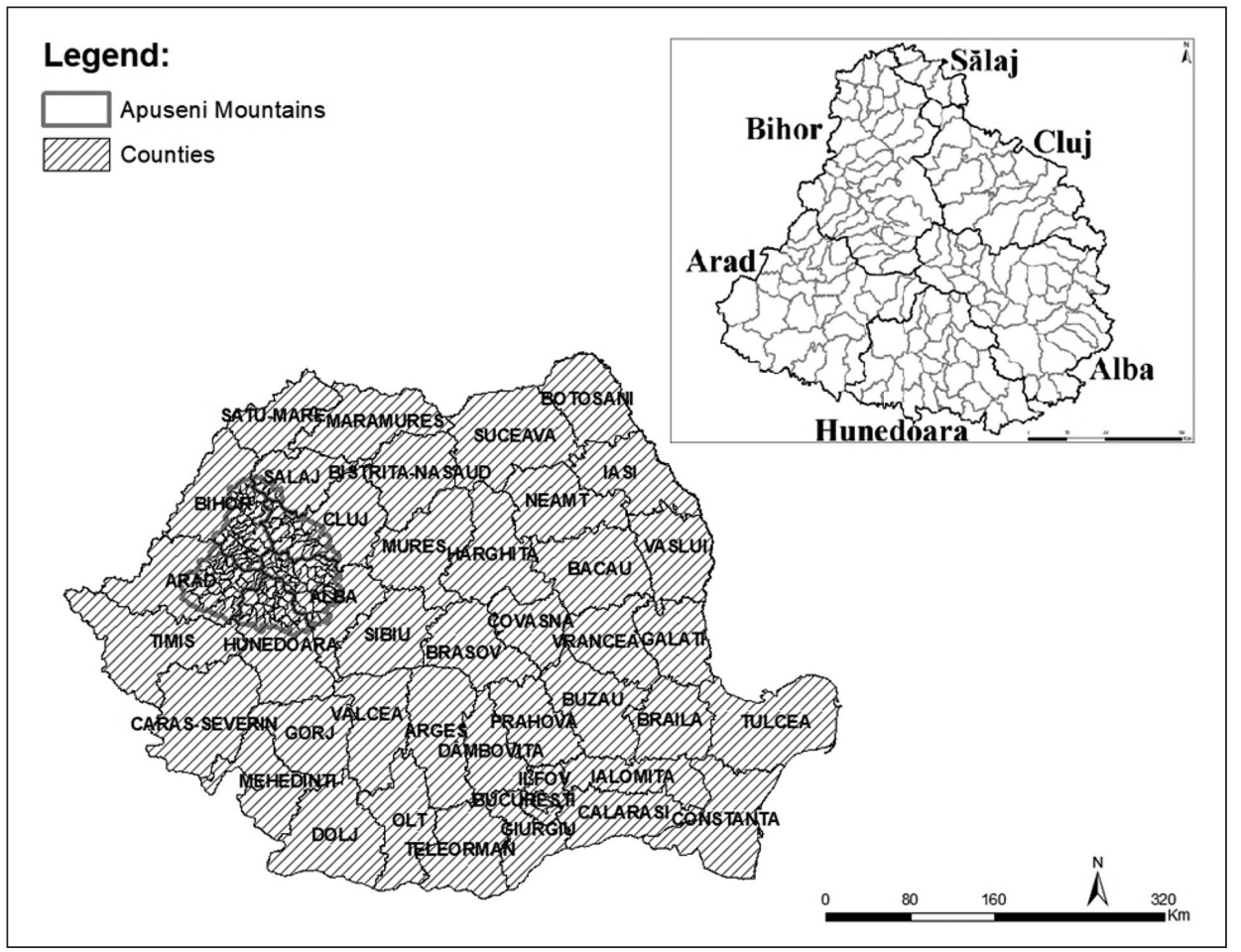

analysis of the settlements in the area, in which demographic, socio-economic and other phenomena are merged into a unique perspective.

The population from the Apuseni Mountains was under research from different angles. Constantin (2011) researched the population and the settlements from the mining areas, identifying dysfunctionalities concerning the dynamics of population. She also advanced several scenarios for reinvigoration at social and economic levels. The demographic risks in the Apuseni Mountains have been observed and studied for the first time after the end of the Socialist period by Surd et al. (2007).

The socialist period in Romania extended for more than four decades, from 1948 to 1989 ( $21^{\text {st }}$ December) and was defined by strong industrialization, especially in cities, which generated an intense rural-urban migration, as well as by agricultural collectivization. Many rural areas, mostly in the mountains, faced the risk of the succumbing to the depopulation phenomenon.

The migration dynamics of population (international-national, rural-urban) have been the subject of study for researchers around the world, being tackled in various ways (Esbenshade, 2007; Çaglar, Nina, 2010; Motomura, 2010; Boswell, Andrew, 
2011; Provine, Gabriella, 2011; Scholten, 2011; Stupariu et al., 2018; Caponio, Jones-Correa, 2018).

\section{METHODOLOGY}

In order to delineate the Apuseni Mountains from a territorial-administrative point of view, and the rural areas implicitly, we used the limits defined by Drăgan (2011) in his study on the resilience of the Apuseni Mountains regional system. In conformity with his delineation, the Apuseni Mountains region includes 153 territorial-administrative units, out of which 13 are towns and 140 are communes. Spatially speaking, the Apuseni Mountains comprise areas from six counties, therefore the article will refer to six regional sub-systems: Alba Apuseni, Arad Apuseni, Bihor Apuseni, Cluj Apuseni, Hunedoara Apuseni, Sălaj Apuseni. Absolute statistical data on emigration and immigration for the two moments in time chosen for analysis (1992 and 2011) have been obtained from the Romanian National Institute of Statistics, from the Tempo - Online platform. The same platform was the source for the number of inhabitants for each commune. The latter was used for calculating the emigration and immigration rates. We point out that data concerning the number of people who left the region and the number of people who came into the region have been taken out from the section in which both internal migration and external migration are registered together. Once we had the data, these have been processed by means of Microsoft Excel 2013, and the rates for each of the two indicators sought after have been obtained. Afterwards, the net migration rate for each commune was calculated. At the same time, we draw up three maps for each year analysed, in order to show spatial distribution of the emigration rate, the immigration rate and the net migration rate. We used ArcGIS 10.3 to generate the maps. The same program was used to draw up the map for the geographic location of the Apuseni Mountains.

\section{RESULTS AND DISCUSSIONS}

Figure 2 shows that there had been 3,799 settlements in the rural areas of the Apuseni Mountains in 1992. Out of these, 27.5\% (1,046) were in Bihor Apuseni sub-region. Nevertheless, only one territorial-administrative unit registered more than 100 settlements (103 in Aștileu commune). Yet Bihor Apuseni sub-region is the most extended and comprises no less than 34 communes. Căbești, Finiș and Roșia communes had only five settlements each.

Arad Apuseni sub-region registered 894 settlements (23,5\%) into its 26 communes, with a maximum value in Târnova (93); and with minimum values registered in Șilindia (9), Archiș (8), Tăuț (7), and Hășmaș (6). 
There were 726 (19.1\%) settlements in the Southern part of the Apuseni Mountains, in the sub-region of Hunedoara County. The highest number of persons (89) settled in Certeju de Sus, seven persons in Bulzeștii de Sus and Luncoiu de Jos, respectively and only one person was registered as having settled in Burjuc.

There were 557 people (14.6\%) settled in Alba Apuseni sub-region, being the only area in the Apuseni Mountains in which there were communes that registered no settlement in the period immediately after the Socialist era (1992). The two such communes were Arieșeni and Ceru-Băcăinți. Similarly, there was also a low number (under 10) of persons who settled in Almașu Mare (8), Blandiana (2), Cricău (5), Horea (4), Întregalde (4), Sălciua (2), Scărișoara (4). The highest number of persons settled was registered in Roșia Montană (56).

Cluj Apuseni sub-region registered 13.5\% (513) out of the total number of persons who immigrated into the Apuseni Mountains region in 1992. It is in this sub-region that the highest number of settlements in the Apuseni Mountains region was registered in 1992, namely in Gilău commune - 116 (22.6\% of the total number of persons settled in Cluj Apuseni sub-region).

Sălaj Apuseni represent the smallest part of the Apuseni Mountains, comprising only five communes. This is the explanation for the small number of settlementsonly 63 (Cizer 11, Halmășd 11, Plopiș 17, Sâg 1, and Valcău de Jos 23).

Figure 2. Numerical distribution of the people settled into the rural areas of the Apuseni Mountains in 1992.

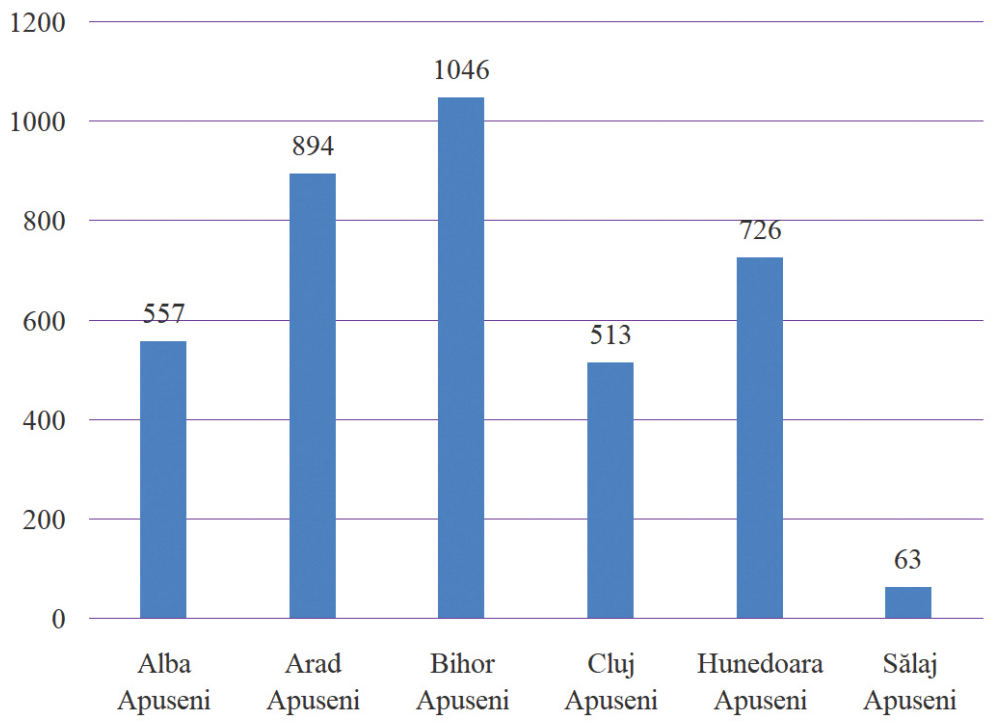

Data source: National Institute of Statistics. 
Spatial distribution of immigration rates (Figure 3) in the Apuseni Mountains in 1992 is characterised by heterogeneity, with lower or higher rates for each of the six sub-regions of the Apuseni Mountains. The highest rate in the entire rural area of the Apuseni Mountains was registered in Arad County sub-region, namely in Moneasa commune $(67.4 \%)$.

Of all the communes with an immigration rate below $10 \%$, most were found in the Alba Apuseni, where $75.7 \%$ of the communes (25) registered values below this threshold, followed by the Bihor Apuseni (22 communes or $64.7 \%$ of this subregion's rural territory), Cluj Apuseni (61.1\% or 11 communes), Arad Apuseni (13 communes or 50\%), Hunedoara Apuseni (11 communes) and Sălaj Apuseni, where none of the five communes registered values above $10 \%$. The highest rate of the entire rural territory of the Apuseni was in the Arad Apuseni, specifically Moneasa (67.4\%o). In the Bihor Apuseni, the highest value was $25.7 \%$, in the commune of Aștileu, also having the highest number of settlers in this part of the Apuseni. Certeju de Sus Commune has the maximum value of immigration in the Hunedoara Apuseni (22.8\%o), while, in the Alba and Cluj Apuseni, the maximum values of the immigration rate do not exceed $20 \%$.

After analysing the data from Figure 3 as well, one might observe that $60 \%$ of the rural areas in the Apuseni Mountains registered immigration rates in the range of $0-10 \%$ in 1992 , followed by rates in the range of $10.1-20 \%$ - with a share of $33 \%$ from the total communes. The lowest values, only $6 \%$ and $1 \%$ respectively, are in the range of $20.1-30 \%$, or above $30 \%$. Thus it is clear that the rural space of the Apuseni Mountains was not a pull factor for population settling in the first years of the post-communist period. Despite 3799 people having settled the rural areas of the Apuseni, the immigration rate remained low $(9.3 \%$ ).

The number of emigrants from the Apuseni Mountains registered for 1992 (Figure 4) was 7308 , as statistical data show.

Out of this number, no less than 1794 (24.5\%) emigrated from Alba Apuseni. This part of the Apuseni Mountains represented one of the most productive mining regions in Romania, with rich silver and gold resources. The majority of population was working in mining industry which, after the 1989 Revolution, experienced an ample restructuring process. This generated massive layoffs, therefore the incomes of the families started to decrease, and workplaces were nowhere to find. Under these circumstances, living standards declined, stimulating the beginning of emigration towards other regions in Romania or even abroad. The average number of employees in industry decreased by 63.5\%, from 1,107 in 1996 to only 404 in 1999. Mining industry registered the most significant dysfunctionalities. In only three years, the number of employees decreased with 63.7\%, from 1,077 in 1996 to only 390 in 1999 (Boțan, Ilovan, 2006, p. 118). Three territorial-administrative units registered over $100 \mathrm{emi}$ grations each: Albac (114), Bistra (142) and Lupșa (137). The economic activities of these communes had been predominantly agricultural, yet approximately $20-30 \%$ of the active population in Albac commune worked in industry. At the same time, more 
Figure 3. Spatial distribution of the immigration rates in the rural areas of the Apuseni Mountains in 1992.

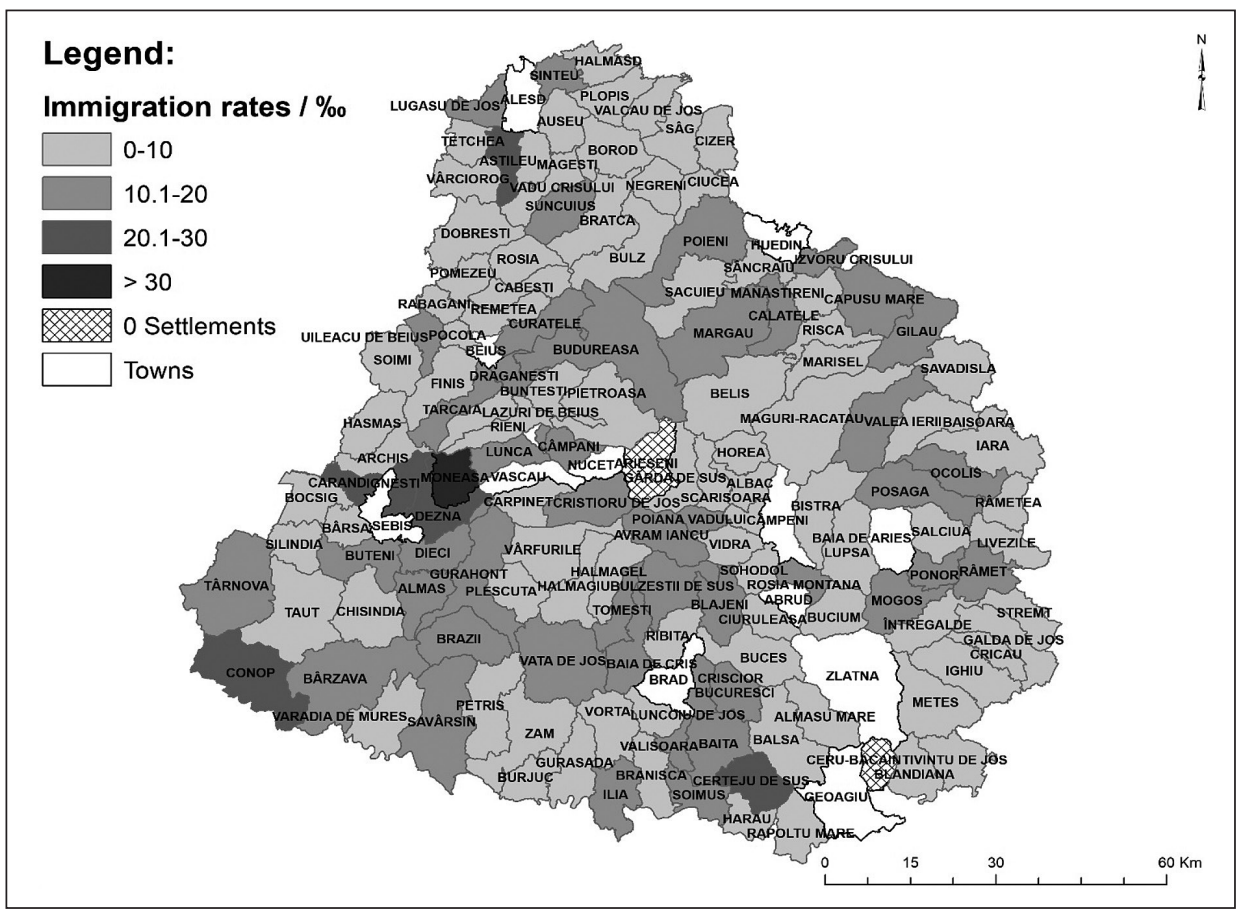

Data source: National Institute of Statistics.

than $40 \%$ of the active population in Bistra commune was incorporated in industry (Mureșan, Boțan, 2015, p. 52).

Bihor Apuseni follows Alba Apuseni. 1,692 people emigrated from here in 1992, which represents $23.1 \%$ out of the total number of emigrants. The mining tradition in Bihor County was similar to the one in Alba County, and the restructuring had similar consequences.

Unfortunately, the same communes which had been predominantly industrial registered the highest number of emigrants. Thus, just the mining area which includes Borod, Dobrești, Șuncuiuș and Vadu Crișului communes registered 20\% out of the total number of emigrations in Bihor county Apuseni Mountains. The highest number of employees in industry in 1992 was 1,390 persons in Dobrești commune, all working in mining. In only eight years, the number of employees working in industry registered a decrease by $87.1 \%$, while in mining there was no employee registered, thus the decrease of $100 \%$. In Șuncuiuș, there were 1,076 employees who worked in industry, 1,065 of them solely in mining. In 2002, the number of employees 
in industry decreased by $78.2 \%$ as compared to 1992 ; and the number of persons working in mining decreased by $93.5 \%$. In Borod, 556 people worked in the industry sector, most (98.9\%) as miners. From 1992 to 1994 there was an increase in the number of miners by $56.7 \%$, a state followed by a decrease to 0 of the persons working in mining during the period 1994-2004. Vadu Crișului was the only commune which had not had miners until 1995, the following year their number being 160 , and until 1998, the number decreased by 64.3\% (Morar, 2011). Under these circumstances, we can conclude that the changes and the layoffs in industry caused major dysfunctions in Bihor Apuseni, leading to population emigration.

19.5\% out of the total number of emigrants from the Apuseni Mountains in 1992 were registered in the Cluj County sub-region. Six territorial-administrative units had more than 100 emigrations registered (Beliș 104; Căpușu Mare 112; Gilău 127; Măguri-Răcătău 132; Poieni 112; Săvădisla 115). The reason people emigrated from Măguri-Răcătău commune was linked to its geographical location, as the commune is located at more than 1,000 m altitude. The lack of workplaces and the poor state of the transportation routes reinforced emigration towards lower-altitude areas, where access to services and workplaces was easier. Căpușu Mare and Săvădisla communes are part of the Călata Land-from an ethnographic point of view (Buș et al., 2017), thus they have a significant number of Hungarian ethnics, some of whom emigrated outside Romania. The high number of Hungarians who emigrated gave a boost to a similar process among the Romanians. In 1992 Săvădisla commune had the following ethnic structure: 52\% Hungarians and 48\% Romanians, while in Căpușu Mare there were $62 \%$ Romanians and 32\% Hungarians. Emigration in Gilău was determined by the small distance-only $16 \mathrm{~km}$-from Cluj-Napoca municipality, a distance which can be covered in optimum traffic conditions in just 15-20 minutes. The inhabitants from Beliș and Poieni communes emigrated towards Huedin town, which offered good prospect for superior life standards, with access to medical and educational services and to workplaces.

Arad Apuseni registered 13.7\% out of the total number of emigrants from the Apuseni Mountains. Nevertheless, only Târnova commune registered more than 100 emigrants, most of them being part of the Ukrainian community.

Hunedoara Apuseni and Sălaj Apuseni sub-regions registered 13.1\% and 5.8\% emigrants, respectively, out of the total number of emigrants from the Apuseni Mountains. Plopiş commune from Sălaj County registered 148 emigrants, the majority being part of the Slovakian community. The beginning of the post-socialist period coincided with a decrease in agricultural and industrial activities to which Slovakians were used to, which determined the migration of the young Slovakians. At the same time, their migration was also due to the lack of education infrastructure in Slovak language (Štefanko, 2004, p. 79). 
Figure 4. Numerical distribution of emigrants in the rural areas of the Apuseni Mountains in 1992.

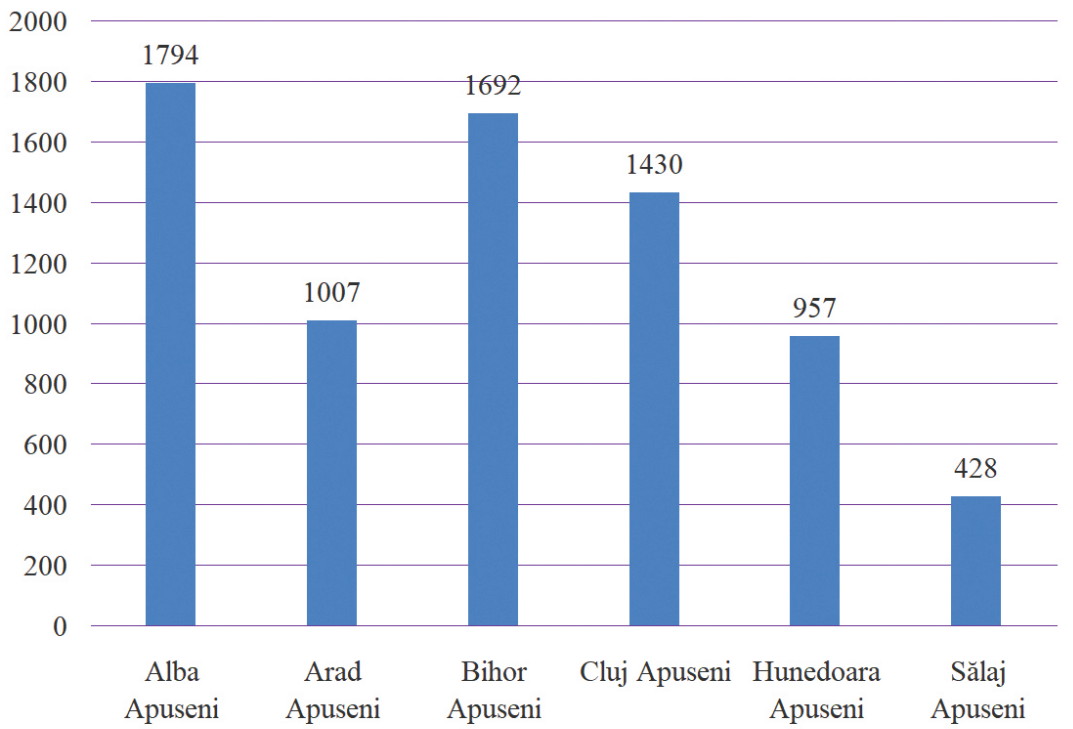

Data source: National Institute of Statistics.

Figure 5 shows the spatial distribution of the emigration rates in the Apuseni Mountains in 1992. The highest rate was registered in Beliș commune-part of Cluj Apuseni. Nevertheless, there had been many territorial-administrative units characterised by a higher number of people who left (more than the 104 in Beliș), yet if compared with the low number of inhabitants of this commune, the rate is $67.3 \%$. In the Apuseni Mountains, this period, which immediately followed the Socialist period, was characterised by high emigration rates. Only seven communes registered values lower than 10\%o (Ighiu from Alba County with 9.2\%o; Burjuc from Hunedoara County with 9.3\%o; Gurahont with 8.2\%o and Buteni with 7.6\%o from Arad County; Câmpani $10 \%$, Curățele $9.3 \%$ and Vârciorog $9.6 \% 0$ - part of Bihor County).

If we compare these with the emigration rates in the urban areas of the Apuseni Mountains, we conclude that migration was prominently more intense in the rural areas. The highest emigration rate in the urban areas in 1992 was $27.5 \%$ in Baia de Arieș in Alba Apuseni, and the lowest was 11.7\%o in Vașcău town in Bihor Apuseni (Lung, Gligor, 2018). 
Figure 5. Spatial distribution of the emigration rates in the rural areas of the Apuseni Mountains in 1992.

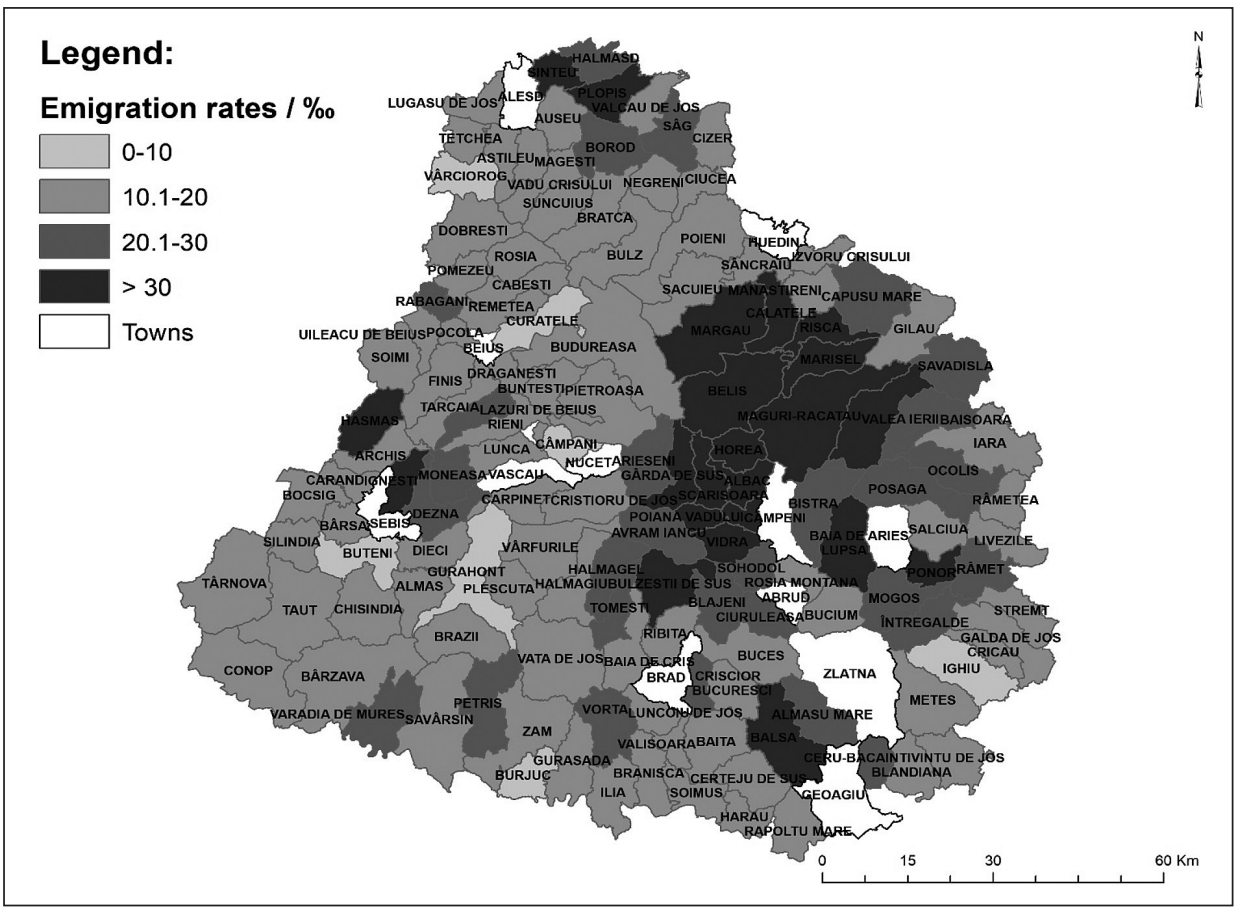

Data source: National Institute of Statistics.

The analysis makes it clear that the year 1992 was characterized by emigration rates in the range of $10.1-20 \%$, with a share of $58 \%$ of the total values of the emigration rate. There follow the rates in the range of $20.1-30 \%$ representing $21 \%$ of the total and the rates that exceed $30 \%$ with $16 \%$, respectively. Thus, we can highlight the excessive emigration of the population from the Apuseni Mountains, following the transition from communism towards capitalism and the social and economic changes that accompanied this transition. The restructuring process in industry determined significant layoffs, which led to a continuous decline in life standards.

The large number of emigrations, as compared to settlements, determined mainly negative net migration rates in the Apuseni Mountains in 1992 (Figure 6). Only 15.7\% (22 communes) of the rural areas in the Apuseni Mountains registered positive net migration rates in 1992 .

Out of the 22 communes, most are located in the Arad Apuseni ( 9 communes), followed by Bihor County ( 7 communes) and Hunedoara Apuseni ( 5 communes). Only Roșia Montană commune registered a positive net migration rate in Alba county 
sub-region. Moneasa commune (Arad County) had registered the highest net migration rate from the entire area of the Apuseni Mountains. This is due to the high value of the rate of immigration (67.4\%o). At the other end, there was Beliș commune-part of Cluj county sub-region-with the lowest net migration rate, a negative one: $-59.5 \%$ (due to a high value of the emigration rate, 67.3\%o).

Figure 6. Spatial distribution of the net migration rates in the rural areas of the Apuseni Mountains in 1992.

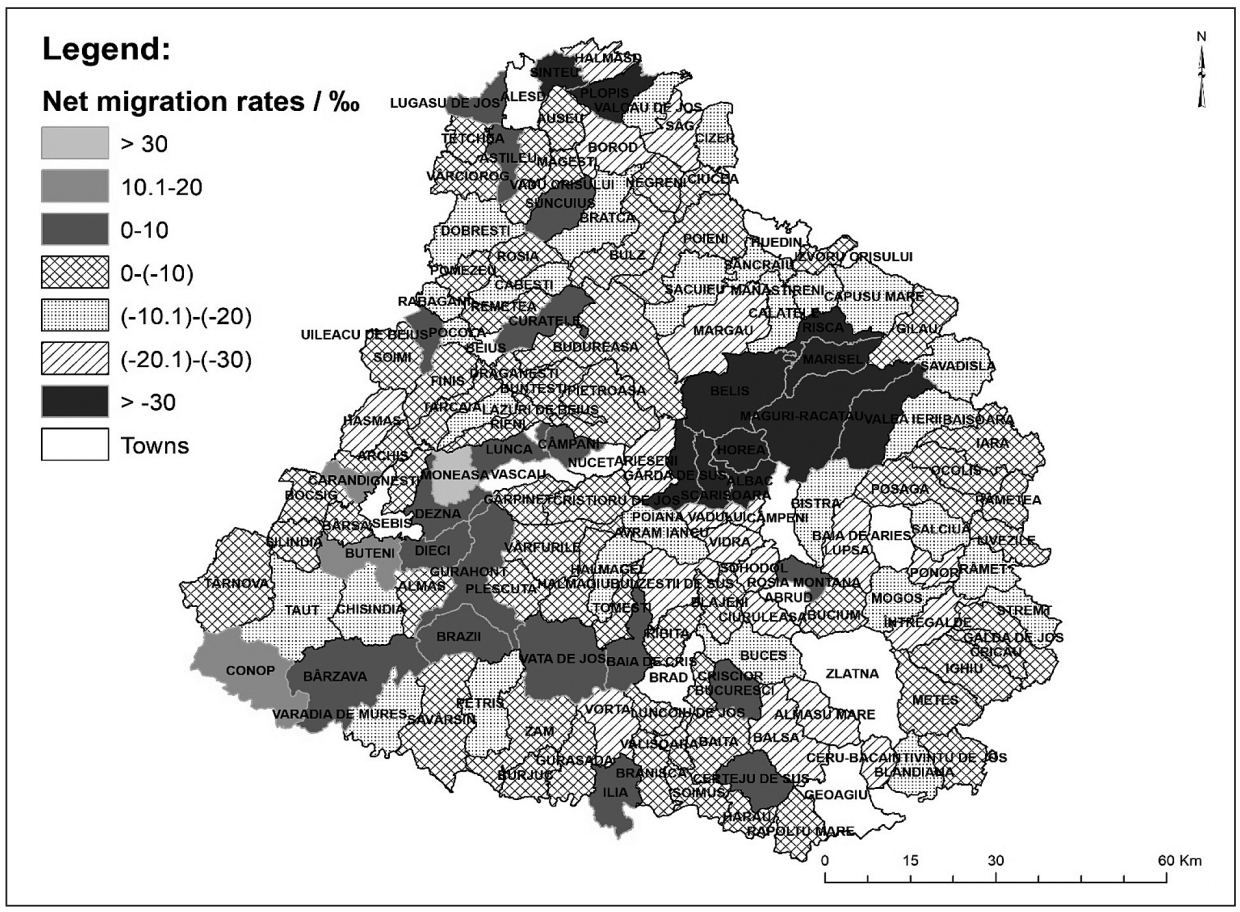

Data source: National Institute of Statistics.

In 2011, the number of settlements in the Apuseni Mountains was 4,653 persons (Figure 7), 22.4\% more than in 1992. 26.5\% out of the total number of settlements was registered in Bihor Apuseni. The commune with the highest number of settlements was Bratca-85 persons; nine persons settled in Șinteu and six in Criștioru de Jos, respectively. After Romania was integrated in the EU, the inhabitants from Bratca started to capitalize on the natural and anthropic potential of their commune through tourism-related activities. Therefore, guesthouses had been built offering good quality accommodation conditions and at fair prices, as compared to other areas. Sinteu commune is dominated in its ethnic structure by Slovaks (96\%), thus being the only administrative 
unit in the Apuseni Mountains with such ethnical dominance. The Slovaks who left immediately after the end of the Socialist era resettled in their native places-places from where they had been brought to colonize the area in the Apuseni Mountains. This explains the low number of people who have settled these lands in 2011.

$20.4 \%$ of the total number of people who settled in the Apuseni Mountains chose Alba County. Ighiu was the commune with the highest number of settlements (122), it is in fact the biggest commune in Alba Apuseni, with 6,283 inhabitants in 2011. On the other hand, there were three communes in which less than 10 people settled. Blandiana 8; Ceru-Băcăinți 7; and Poșaga 9. Unfortunately, besides the fact that these communes have a low number of inhabitants (Blandiana 923; Ceru-Băcăinți 269; and Poșaga 1,048), the age structure shows a high share of the population over 65 years old: $25.8 \%$ in Blandiana; $27.1 \%$ in Ceru-Băcăinți, and 31.4\% in Poșaga. These high shares of old-age population have an influence on migration. In fact, Ceru-Băcăinți is the commune with the lowest number of inhabitants in the Apuseni Mountains.

$18.1 \%$ of the settlements from the total number registered in 2011 were in Arad Apuseni. Nevertheless, when compared to 1992, the settlements decreased by 5,5\%. Târnova commune was in first place, with 109 settlements, in the context of Ukrainians' migration. The lowest number of settlements was registered in Brazii commune, only nine persons.

Hunedoara Apuseni integrated $16.8 \%$ of the persons settled in the rural areas of the Apuseni Mountains as a whole. As compared to 1992, there has been an increase of $7.9 \%$. The highest number-80 inhabitants-was registered in Șoimuș commune, and the lowest number (8 inhabitants settled) in Vorța commune.

$15.2 \%$ of the total number of persons who settled in the rural areas of the Apuseni Mountains chose Cluj County. As compared to 1992, 2011 registered an increase of $6.9 \% .145$ persons settled in Gilău-the commune with the highest number of persons settled. The fact that there are only $16 \mathrm{~km}$ between Gilău and the city of Cluj-Napoca represented a favourable factor to determine the migration, in the context of lower real estate prices. At the same time, life standards in Gilău improved as compared to 1992-projects had been implemented that facilitated works on urban and technical infrastructure (drinking water distribution system; sewerage system, gas distribution system). Izvoru Crișului commune registered the lowest number of persons settledonly 12 . It is a territorial-administrative unit inhabited by $80 \%$ Hungarian ethnics, who migrated mainly in the first years of the post-socialist period. The major part of the population stayed in the commune and, with time, they started various family businesses to support them economically. In general, these businesses focus on selling handcraft products.

$3.8 \%$ of the population who immigrated in the Apuseni Mountains settled in Sălaj county sub-region. The highest number of persons settled was 46 in Cizer commune-mainly represented by Roma people. Their number increased by $63.6 \%$ as compared to 1992. There were no more Hungarians and Slovaks in Cizer commune in 2011 
and the Romanian population decreased by $26.1 \%$ as compared to 1992 . There were 23 people who settled in Halmășd commune, the minimum value in Sălaj County in 2011.

Figure 7. Number of persons settled in the rural areas of the Apuseni Mountains in 2011.

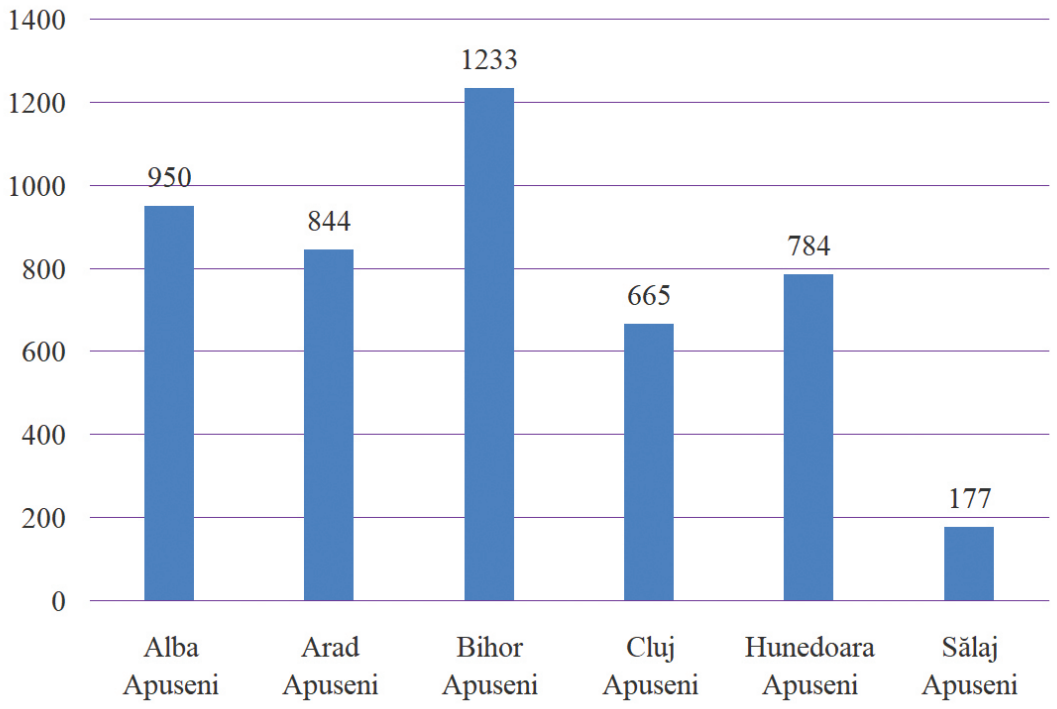

Data source: National Institute of Statistics.

Figure 8 shows the geographic distribution of the immigration rates in the rural areas of the Apuseni Mountains in 2011. The highest values of the immigration rate in the entire rural territory of the Apuseni were registered in the communes of Ponor, Alba Apuseni (59.3\%o), Bulzeștii de Sus-part of Hunedoara county sub-region (40.6\%o), Pleșcuța in Arad County (27.9\%o) and Valea Ierii in Cluj County (27\%o). Two other communes (one in the Bihor Apuseni, the other in the Sălaj Apuseni) exceed the value of $20 \%$ for the rate of immigration. The lowest values, below $10 \%$, were found in 31 communes (22\% of the entire rural space): 10 communes in the Bihor Apuseni, 8 in the Alba Apuseni, 6 in the Cluj Apuseni, 3 in the Arad Apuseni and Hunedoara Apuseni each and one in the Sălaj county subregion. 
Figure 8. Spatial distribution of the immigration rates in the rural areas of the Apuseni Mountains in 2011.

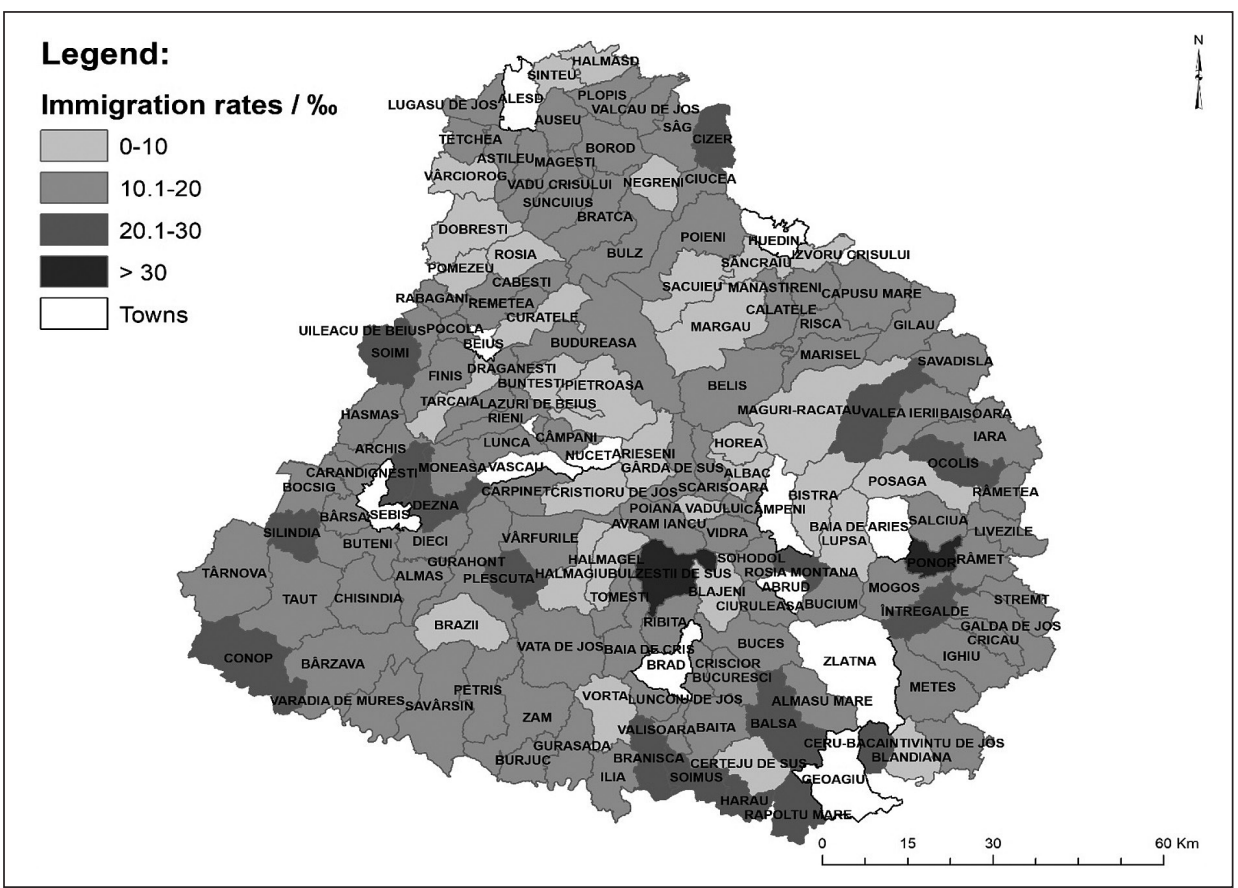

Data source: National Institute of Statistics.

In terms of the immigration rates percentage distribution in the Apuseni Mountains in 2011, 65\% of the rural areas in the Apuseni Mountains was characterised by rates between 10.1 and $20 \%$, and $22 \%$ of the territorial-administrative units registered rates between 0 and $10 \%$. Only $12 \%$ of the communes had rates between 20.1 and $30 \%$ and only $1 \%$ had rates over $30 \%$.

Figure 9 presents the evolution of emigration in the rural areas of the Apuseni Mountains in 2011. Emigrations decreased by $38.8 \%$ that year as compared to 1992 . Thus, there were 4,471 persons registered to have left from the rural areas of the Apuseni Mountains in 2011. 1,246 persons left from Bihor County, a decrease of 26.3\% as compared to 1992 . The highest number of emigrants was registered in Dobrești (75), and the lowest number in Pocola (13). If Alba county sub-region registered the highest number of emigrations in 1992, in 2011 the number of emigrants decreased by $48.4 \%$. Ceru-Băcăinți and Livezile communes registered the lowest number of emigrants of 6 and 7, respectively. Emigrations from Arad county sub-region decreased with 17.6\%, the highest number of emigrants being registered in Târnova (92), and the lowest in Șilindia (11). Emigrations in Hunedoara County decreased by $34.3 \%$ as compared to 1992 , the highest number of 
emigrants being 54 registered in Certeju de Sus, while Bulzeștii de Sus and Burjuc registered only 7 and 8 emigrants, respectively. Emigrations from Cluj county sub-region decreased as compared to 1992, with no less than $56.5 \%$. Gilău registered 84 emigrants, and Sâncraiu-the lowest number of emigrants (only nine). Sălaj Apuseni registered a decrease of $48.1 \%$ as compared to 1992.56 persons emigrated from Sâg, and the lowest number of emigrants was registered in Valcău de Jos (33). Unfortunately, these decreases in emigrations did not contribute to the improvement of the demographic context in the Apuseni Mountains, when they are matched with the population number. From 1992 to 2011, the population in the rural areas of the Apuseni Mountains decreased with 15\%. The major part of population emigrated in the first years that followed the Socialist era; there had been 7,308 emigrations in 1992, and 4,471 in 2011. In effect, the 11,779 emigrations registered in the two years analyzed represent $12.3 \%$, when matched with the rural population of the Apuseni Mountains in 2011.

Figure 9. Numerical distribution of emigrations in the rural areas of the Apuseni Mountains in 2011.

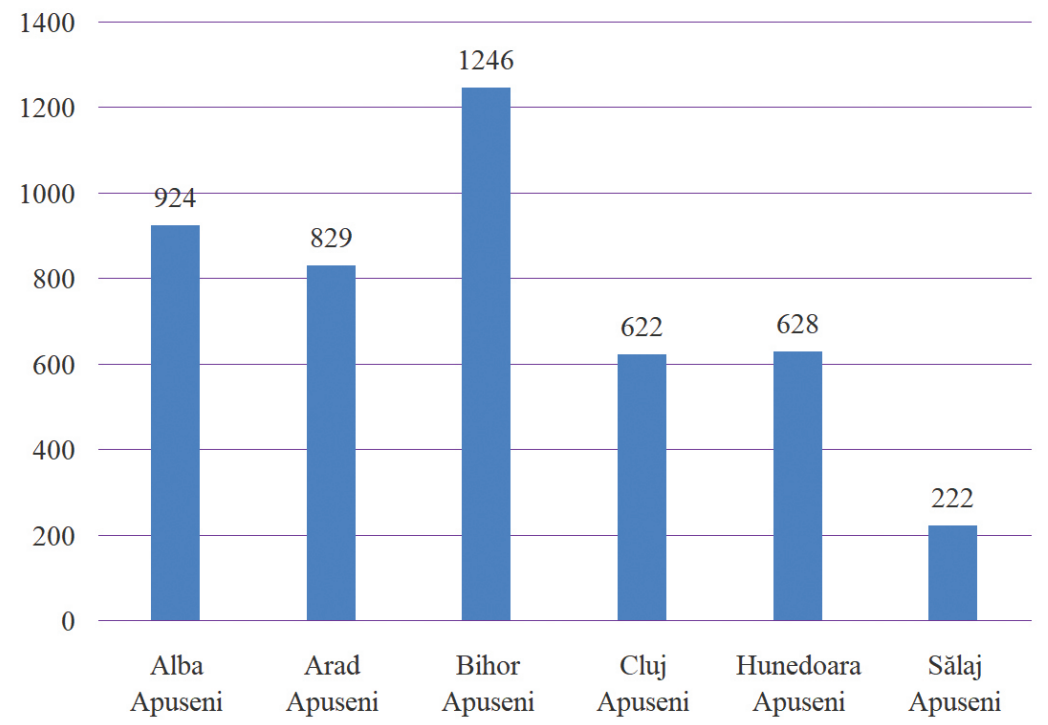

Data source: National Institute of Statistics.

Figure 10 presents the geographical distribution of the emigration rates in the rural areas of the Apuseni Mountains in 2011. The highest emigration rate that year was 40,1 \%o in Râmeț commune, part of Alba county sub-region, and the lowest was 5,5 \%o in Sâncraiu, part of Cluj county sub-region. Only three communes exceeded the value of $30 \%$ (Râmeţ in the Alba Apuseni, Moneasa in the Arad Apuseni and Vorţa in the Hunedoara Apuseni), while 24 communes registered values below $10 \%$. 
Figure 10. Spatial distribution of the emigration rates in the rural areas of the Apuseni Mountains in 2011.

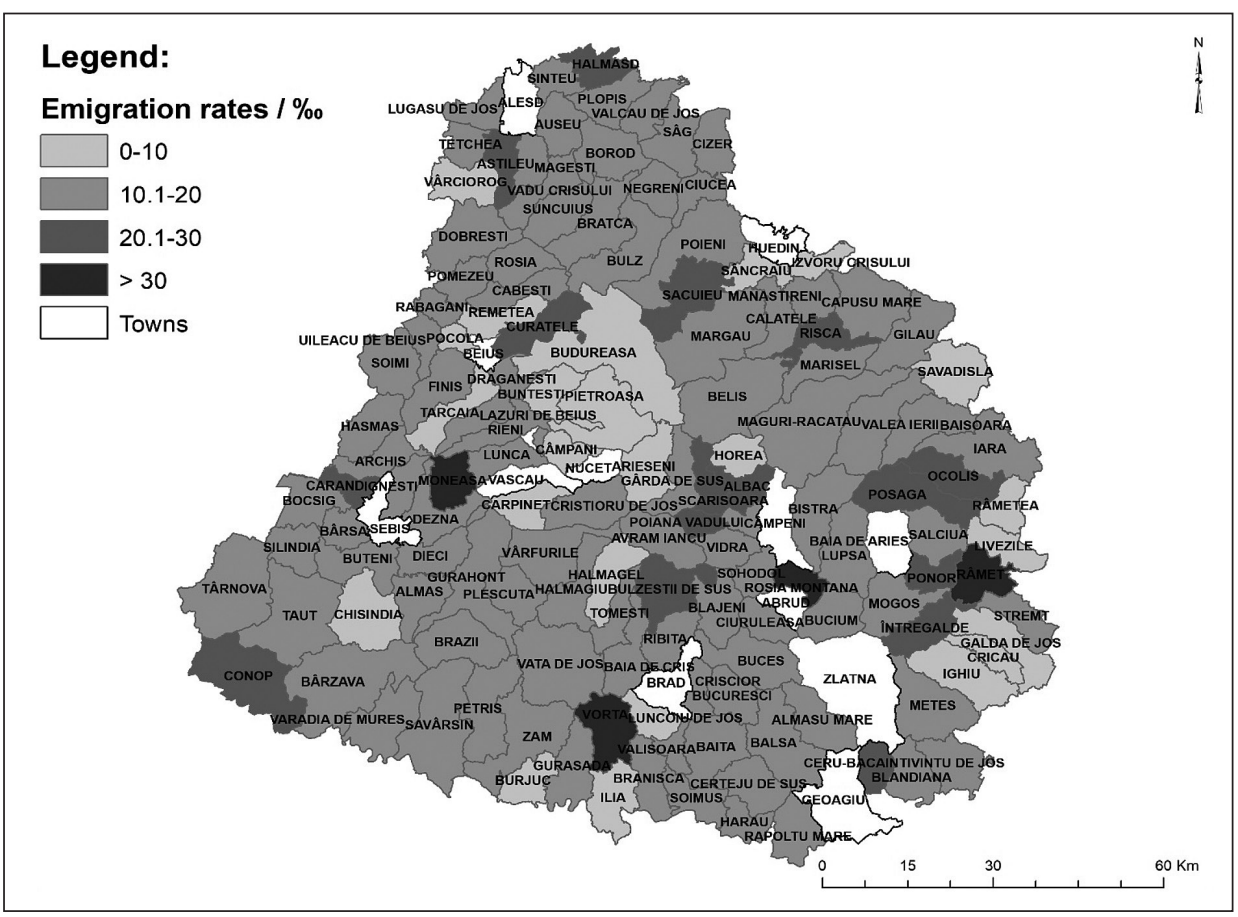

Data source: National Institute of Statistics.

Regarding the percentage distribution of the emigration rates in the rural areas of the Apuseni Mountains in 2011, it is clear that the rates between 10.1 and $20 \%$ are dominant with $69 \%$ of the total emigration rate values, followed by the rates between 0 and $10 \%$ with $17 \%$. Higher rates-between 20.1 and $30 \%$ - have a share of $11 \%$, and the highest ones-over $30 \%$ - are only $1 \%$.

In 2011, positive net migration rates (Figure 11) were higher in number than in 1992. 55.7\% of the rural areas in the Apuseni Mountains registered positive rates, and $88.4 \%$ of these had values between 0 and $10 \%$. This implies that, in numerous communes, the difference between settlers and emigrants is not significant, with possible dysfunctions that may generate a negative migratory balance. The highest net migration rate of the whole rural area in the Apuseni Mountains was 37\%o in Ponor commune-part of Alba Apuseni. At the other end, there was Vorța commune in Hunedoara Apuseni, which registered a net migration rate of $-25.1 \%$. Besides Ponor commune, there had been eight communes which registered net migration rates over 10\%o: Bulzeștii de Sus 14.8\%o; Galda de Jos 10.6\%o; Hărău 12.6\%0; Rapoltu Mare 11.2\%o; Săvădisla 11.6\%o; Șilindia $14.4 \%$; Șoimuș $13.1 \%$; Valea Ierii $10.1 \%$. At the 
same time, we need to emphasize that we identified eight communes in which the net migration rate was 0 , the number of the persons settled being equal to the number of the persons who emigrated: Almașu Mare, Avram Iancu, Beliș, Buntești, Buteni, Ocoliş, Pietroasa, and Sălciua.

Figure 11. Spatial distribution of the net migration rates in the rural areas of the Apuseni Mountains in 2011.

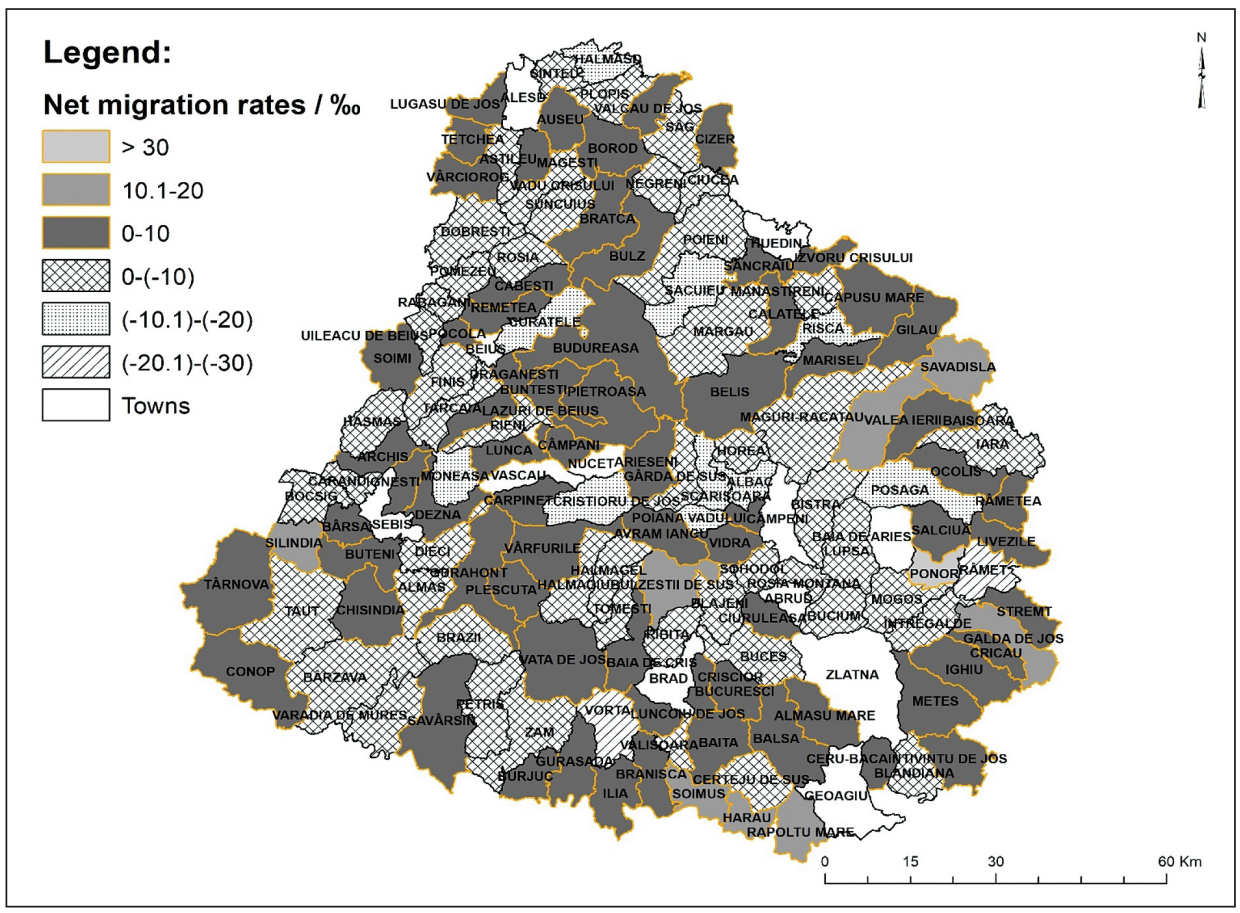

Data source: National Institute of Statistics.

\section{CONCLUSIONS}

Emigration primarily leads, in the case study area, to a decrease in the number of inhabitants which, in turn, can cause depopulation. As most emigrants are young people and adults, it also considerably disrupts the population age structure, with increases in the percentage of people over 60 years of age, thus causing demographic aging to set in. These two phenomena, which can be viewed as demographic risks, have the most significant negative impact on the functionality of the territorial system of the Apuseni Mountains (Boţan, 2010).

It can be said that the rural areas of the Apuseni Mountains are fragile from the migration dynamics point of view. In 1992, the number of the emigrants was higher than the 
number of the people who settled in the area. Therefore, negative net migration rates were registered in the most parts of the rural areas. Unfortunately, industrial restructuring unbalanced life conditions, which stimulated migration. As we have stated, mining communes lost population constantly due to the layoffs, as the employees made redundant were forced to emigrate in order to find another workplace by which to support their families. In 2011, the migration situation was better. Population emigrated in lesser numbers, as the major part of those who emigrated in 1992 were young, therefore they left behind an aging population. The seniors were no longer interested in emigrating, as they had gotten used to the place where they had been living all their lives, some of them living by animal husbandry, others by crop farming. In fact, one can conclude that the positive net migration rates registered in 2011 are not high, the major part being in the range of $0-10 \%$.

Unfortunately, the migratory dynamic in the Apuseni Mountains, alongside low birth rates, affects the school age population as well. The number of pupils in the rural areas of the Apuseni has continuously decreased during the post-communist period, with massive drops in student numbers. The most significant declines in school age populations took place in 13 administrative-territorial units: Blăjeni, Bucium, Ceru-Băcăinți, Ciucea, Întregalde, Livezile, Mogoș, Moneasa, Ocoliș, Râmeț, Râșca, Șinteu, and Tomești. The shrinkages in these administrative units were over 70\% (Lung, 2019).

Under these conditions, the demographic component of the rural areas in the Apuseni Mountains continues to be vulnerable to depopulation phenomena, as there is a lack of efficient measures from the part of the decision makers.

\section{References}

Boswell, C., Andrew, G., 2011. Migration and mobility in the European Union. Basingstoke: Palgrave Macmillan.

Boţan, C. N., 2010. Ţara Moţilor. Studiu de Geografie Regională [The Land of Moţi. Study of Regional Geography]. Cluj-Napoca: Presa Universitară Clujeană.

Boțan, C. N., Ilovan, O-R., 2006. Trends of industrial reconversion in the Land of the Moți. Romanian Review of Regional Studies, 2, 1, pp.113-120.

Buş, R-M., Lung, M-S., Colcer, A-M., 2017. Traditional crafts and folklore as a means of economic development in the Land of Călata. Territorial Identity and Development, 2, 1, pp. 64-77.

Çaglar, A., Nina, G-S., 2010. Introduction. Migrants and cities. In: Glick Schiller, N., Çaglar, A. (ed.). Locating migration: Rescaling cities and migrants. Ithaca, NY: Cornell University Press, pp. 5-24.

Caponio, T., Jones-Correa, M., 2018. Theorising migration policy in multilevel states: The multilevel governance perspective. Journal of Ethnic and Migration Studies, 44, 12, pp. 1995-2010. DOI: 10.1080/1369183X.2017.1341705.

Cândea, M., Cimpoeru, I., Bran, F., 2006. Organizarea, amenajarea şi dezvoltarea durabilă a spaţiului geografic [Organization, spatial planning and sustainable development of geographic space]. Bucureşti: Editura Universitară. 
Constantin, V., 2011. Aşezările din arealele miniere din Munţii Apuseni: studiu de geografie aplicată [The settlements in the mining areas in the Apuseni Mountains: applied geography study]. Doctoral thesis. Cluj-Napoca: Babeş-Bolyai University of Cluj-Napoca, Faculty of Geography.

Drăgan, M., 2011. Rezilienţa sistemului regional Munţii Apuseni” [Resilience of the Apuseni Mountains regional system]. Doctoral thesis. Cluj-Napoca: Babeş-Bolyai University of Cluj-Napoca, Faculty of Geography.

Esbenshade, J., 2007. Division and dislocation: Regulating Immigration through local housing ordinances. Washington, DC: American Immigration Law Foundation.

Lung, M-S., 2019. The evolution of the school population in the Carpathian mountain space. Case study: urban and rural environment of Apuseni Mountains (Romania). Geograficando, 15, 1, e049. DOI: 10.24215/2346898Xe049.

Lung, M-S., 2018. The natural dynamics of the rural population in Apuseni Mountains (2011 Census). Romanian Review on Political Geography/Revista Română de Geografie Politică, 20, 2, pp 41-48.

Lung, M-S., Gligor, V., 2018. Demographic changes in the urban space of Apuseni Mountains. Analele Universității din Oradea, seria Geografie. 28, 2, pp 64-173.

Morar, C., 2011. Several social impacts of mine closures in the disadvantaged areas of Bihor County, Romania. Forum geografic. Studii şi cercetări de geografie şi protecţia mediului, 10, 2, pp 303-311.

Motomura, H., 2010. Immigration outside the law. Columbia Law Review, 108, pp. 2037-2097.

Mureșan, G. A., 2016. Regiuni critice [Critical regions]. Cluj-Napoca: Editura Risoprint. Mureșan, G-A., Boțan, C-N., 2015. The socio-occupational structure of the population in the Apuseni Mountains. Case study: the Land of the Moţi. Romanian Review of Regional Studies, 11, 2, pp $49-56$.

National Institute of Statistics, Tempo - Online. Dataset. URL: http://statistici.insse. ro:8077/tempo-online/\#/pages/tables/insse-table (accessed 01.10.2018).

Pop, G., 2000. Carpații și Subcarpații României [Carpathians and Sub-Carpathians of Romania]. Cluj-Napoca: Editura Presa Universitară Clujeană..

Provine, D-M., Gabriella, S., 2011. Suspecting immigrants: Exploring links between racialised anxieties and expanded police powers in Arizona. Policing and Society, 21, 4, pp. 468-479.

Scholten, P., 2011. Framing immigrant integration: Dutch research-policy dialogues in comparative perspective. Amsterdam: Amsterdam University Press.

Štefanko, O., 2004. Despre slovacii din România [About Slovaks in Romania]. Nadlak: Editura Vydavatel'stvo Ivan Krasko.

Stupariu, M. I., Herman, G. V., Grama, V., 2018. The structure of migration flows from Romania to Italy (2008-2016). Romanian Review on Political Geography/Revista Româna de Geografie Politica, 20, 1, pp. 5-16. 
Surd, V., Zotic, V., Puiu, V., Moldovan, S. C., 2007. Riscul demografic în Munții Apuseni [Demographic risk in the Apuseni Mountains]. Cluj-Napoca: Editura Presa Universitară Clujeană.

\section{MIGRACIJSKA DINAMIKA PODEŽELSKEGA PREBIVALSTVA V GORSKI POKRAJINI APUSENI V POSTSOCIALISTIČNEM OBDOBJU}

\section{Povzetek}

Izseljevanje lahko, tako kot na območju študije primera, vodi v zmanjšanje števila prebivalstva, kar lahko povzroči depopulacijo. Ker je večina izseljencev mladih oziroma mlajših odraslih, proces izseljevanja zelo vpliva tudi na starostno strukturo prebivalstva, saj se poveča delež starejših od 60 let, kar povzroča staranje prebivalstva območja. In ravno omenjena procesa, izseljevanje in staranje prebivalstva, imata zelo velik vpliv na podeželska naselja gorskega območja Apuseni v Romuniji.

Z vidika migracijske dinamike so podeželska območja v gorstvu Apuseni zelo ranljiva. Leta 1992 je bilo število izseljenega prebivalstva večje od priseljenega, zato so $\mathrm{v}$ večini podeželskih naselij zabeležili negativni selitveni prirast. V naslednjih letih pa je gospodarska preobrazba območja izselitvene procese še pospešila. Rudarske občine so zaradi odpuščanja delavcev pričele izgubljati prebivalstvo, saj so bili odpuščeni delavci prisiljeni poiskati si zaposlitev drugje, da bi lahko preživeli svoje družine. Leta 2011 je bila migracijska dinamika nekoliko boljša. Prebivalstvo se tega leta ni tako intenzivno izseljevalo; a to predvsem zaradi dejstva, da se je leta 1992 odselila večina mladega prebivalstva, medtem ko je starejše prebivalstvo, ki ni bilo nagnjeno kizseljevanju, ostalo. Starejše prebivalstvo je sprejelo tamkajšnji način življenja in preživljanja s kmetovanjem (vzrejo živine oziroma pridelavo poljščin). Za leto 2011 smo tako zabeležili rahlo pozitivno stopnjo selitev (0-10\%).

Migracijska dinamika v podeželskih naseljih gorstva Apuseni vpliva na nizko rodnost ter s tem tudi na šolsko populacijo. Po padcu komunizma se je število šolske populacije na teh območjih stalno zmanjševalo. Največji upad šolajoče se populacije je bilo zaznati v 13 upravno-teritorialnih enotah: Blăjeni, Bucium, Ceru-Băcăinți, Ciucea, Întregalde, Livezile, Mogoș, Moneasa, Ocoliș, Râmeț, Râșca, Șinteu in Tomești.

Demografska dinamka je v podeželskih naseljih gorskega območja Apuseni še danes zelo občutljiva, saj s strani različnih deležnikov odločanja primanjkuje učinkovitih ukrepov.

(Prevedla Mojca Ilc Klun) 